\title{
BIOCHEMICAL INDEXES OF TISSUES IN SOME COMMERCIAL FISH SPECIES AT THE ZAPORIZKE RESERVOIR (UKRAINE)
}

\author{
Ananieva Tamila*, Fedonenko Elena \\ Oles Honchar Dnipro National University, Dnipro, Ukraine
}

\section{БІОХІМІЧНІ ПОКАЗНИКИ ТКАНИН ДЕЯКИХ ПРОМИСЛОВИХ ВИДІВ РИБ ЗАПОРІЗЬКОГО ВОДОСХОВИЩА (УКРАЇНА)}

\author{
Ананьєва Таміла, Федоненко Олена \\ Received 23. 6. 2017 \\ Revised 26. 6. 2017 \\ Published 24.11. 2017
}

\begin{abstract}
The purpose of the work was to study the ecological and physiological state of the industrial ichthyofauna of the Zaporizke Reservoir on the basis of biochemical analysis of tissues and organs of fish with different types of nutrition and habitat in modern conditions. The indexes of protein, total lipids, and glycogen contents had been determined in the main commercial fish species from two sections of the Zaporizke Reservoir (Ukraine) with different contamination levels. The research was conducted using the muscle, liver and gills tissue samples from pike-perch (Sander lucioperca L.), European perch (Perca fluviatilis L.), bream (Abramis brama L.), and roach (Rutilus rutilus L.). Subjects were selected by standard methods of research control catches at the lower section of the Zaporizke Reservoir area near the Viyskove village $\left(48^{\circ} 22^{\prime} 30.75^{\prime \prime} \mathrm{N} ; 35^{\circ} 20^{\prime} 80.05^{\prime \prime} \mathrm{E}\right)$, which is characterized by environmental conditions as "conventionally clean", and Samara Bay ( $48^{\circ} 53^{\prime} 40.21^{\prime \prime} \mathrm{N} ; 35^{\circ} 18^{\prime} 73.20^{\prime \prime} \mathrm{E}$ ) as technogenically contaminated zone. In predatory fish in the muscles and liver tissue there were the higher protein contents, due to the peculiarities of their nutrition. The processes of carbohydrate and lipid metabolism were most susceptible to deterioration of the environment, as it was evidenced by a statistically significant $(p \leq 0.05)$ reduction in the contents of both glycogen and total lipids in the liver tissues in fish from the "contaminated" zone of the reservoir. Violations of plastic and energy exchange were exposed, that they had a chronic character. Obtained data could be used for estimation of food quality of the explored industrial-valuable fishes of the reservoir, and for the diagnostic prognoses of the ecological and physiological state of fish populations under the conditions of anthropogenic loading.
\end{abstract}

Keywords: commercial fishes; biological tissues; protein content; total lipids; glycogen; Zaporizke reservoir

\section{Вступ}

Риба $\epsilon$ цінним промисловим продуктом, що представляє харчову цінність для людини, тому біохімічна індикація рибної сировини дає важливі критерії для оцінки якості рибних запасів та їх сільськогосподарської значущості. За рахунок якісної рибної продукції можливо вирішити проблему білкового дефіциту, що здебільшого відчуває людина (Hadjinikolova, 2008; Ананьєва та ін., 2013; Porto et al., 2016). У складі тканин риб присутні всі білкові компоненти

*Corresponding author: Tamila Ananieva, Oles Honchar Dnipro National University, Dnipro, Ukraine, $\triangle$ ananieva.tamila@gmail.com 
й амінокислоти, які необхідні для нормальної життєдіяльності людини. Основними біохімічними показниками загального стану риб $є$ вміст білків, жирів та вуглеводів уїї тканинах. Аналіз цих параметрів дозволяє оцінити стан рибних запасів у природних водоймах в умовах трансформації внаслідок антропогенного впливу на водні екосистеми (Федоненко та ін., 2012; Fedonenko et al., 2016).

В умовах тотального забруднення поверхневих водойм питання фізіолого-біохімічного моніторингу природних популяцій риб стають все більше актуальними.

В системному еколого-біологічному тестуванні риб в умовах техногенної трансформації водних екосистем важливе значення мають закономірності пластичного та енергетичного обміну, які відображають фізіолого-біохімічний статус організму протягом річного життєвого циклу (Образова и др., 2016; Fedonenko, Ananieva, 2016).

Виходячи з вищенаведеного, метою роботи стало дослідження еколого-фізіологічного стану представників промислової іхтіофауни Дніпровського водосховища на підставі біохімічного аналізу тканин і органів риб з різним типом харчування та середовищем існування в сучасних умовах.

\section{Матеріали та методи}

Для дослідження були вибрані чотири види риб, які $\epsilon$ характерними для промислових виловів у Запорізькому водосховищі й відрізняються за способом існування та спектром харчування: лящ (Abramis brama L.) - типовий бентофаг, раціон якого містить ракоподібних, молюсків, личинок комах, рослинність; плітка (Rutilus rutilus L.) - споживає рослинність, фітопланктон і зоопланктон; судак (Sander lucioperca L.) та окунь (Perca fluviatilis L.) - хижаки, харчуються рибою. Проби риби відбиралися на двох ділянках Запорізького водосховища, найбільше освоєних у промисловому навантаженні: нижній біля с. Військове $\left(48^{\circ} 22^{\prime} 30.75^{\prime \prime} \mathrm{N}\right.$; $35^{\circ} 20^{\prime} 80.05$ “Е) та Самарській затоці (48 53' 40.21“ N; 35 18’ 73.20 “Е), розташованій в місці впадіння р. Самари в Запорізьке водосховище. Для дослідження статевозрілих особин віком 3-4 роки обох статей, які мали приблизно однаковий розмір та вагу, відбирали за стандартною методикою (Методи..., 2006) у листопаді 2016 р. у двох районах Запорізького водосховища, що характеризувалися за екологічними умовами як "умовно чиста" і "забруднена" зони. Тканину м'язів, печінки та зябер відокремлювали, подрібнювали й визначали вміст загального білка методом Лоурі, вміст загальних ліпідів - методом Фолча, вміст глікогену - антроновим методом Зейфтера (Прохорова, 1982). Одержані цифрові дані піддавали статистичній обробці за допомогою загальноприйнятих методів варіаційної статистики для малої вибірки. Вірогідність розбіжностей між показниками оцінювали за t-критерієм Ст'юдента для парних показників при рівні значущості $p \leq 0,05$.

\section{Результати та їх обговорення}

Запорізьке водосховище розташоване на території Дніпропетровської та Запорізької адміністративних областей України. Знизу водосховище обмежено греблею Дніпрогес біля м. Запоріжжя, зверху - греблею Дніпродзержинської ГЕС у м. Кам'янське. Об'єм водосховища - 3,2 км³, площа - $420 \mathrm{~km}^{2}$, довжина - близько 170 км, ширина - від 0,6 км, у районі затоплених порогів, до 3,5 км, у верхній частині, середня глибина - 8 м, найбільша 45 м. Водоймище характеризується доброю проточністю - водообмін здійснюється

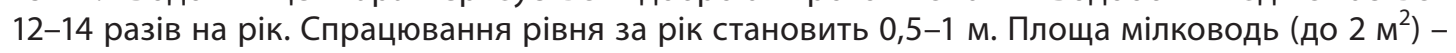
36 \%. За гідрохімічними показниками нижня ділянка водосховища вважається екологічно умовно чистою, а Самарська затока - стійкою зоною токсифікації, токсикологічний режим якої формується під впливом води середньої за водністю степової ріки Самара (річний стік у середньому складає 500 млн м³), куди потрапляють високомінералізовані скидні води Західного Донбасу. Вода у Самарській затоці відзначається високою мінералізацією 
(3 200 мг/дм³) і вмістом важких металів, влітку прозорість води складає 120 м, вміст кисню

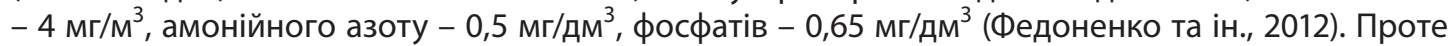
завдяки великій площі мілководь, слабкій проточності і добре розвиненій кормовій базі це один із основних нерестових районів (1,5 тис. га нерестилищ).

Результати досліджень щодо визначення вмісту білка в тканинах промислових риб Запорізького водосховища представлені в таблиці 1. 3 отриманих результатів видно, що м'язова тканина містить найбільшу кількість білка у порівнянні з печінкою та зябрами. Якщо порівнювати між собою риб, які ведуть хижий і мирний спосіб життя, бачимо, що у біологічних тканинах хижаків вміст білка вищий. Це пояснюється тим, що хижаки споживають білкову їжу і їм необхідна більша кількість поживних і енергетичних речовин, оскільки вони ведуть більш рухомий спосіб життя.

Таблиця 1 Вміст білка у тканинах промислових риб Запорізького водосховища (г/100 г сухої маси, $\mathrm{M} \pm \mathrm{m}, n=8$ )

Table 1 The protein content in tissues of commercial fishes from the Zaporizke Reservoir $(\mathrm{g} / 100 \mathrm{~g}$ of dry weight, $\mathrm{M} \pm \mathrm{m}, n=8$ )

\begin{tabular}{|l|c|c|c|c|c|c|}
\hline \multirow{2}{*}{ Вид риби } & \multicolumn{3}{|c|}{ Нижня ділянка водосховища } & \multicolumn{3}{c|}{ Самарська затока } \\
\cline { 2 - 7 } & м'язи & зябра & печінка & м'язи & зябра & печінка \\
\hline Окунь & $92,7 \pm 3,1$ & $55,2 \pm 2,2$ & $51,3 \pm 3,1$ & $86,6 \pm 0,5$ & $42,3 \pm 1,09^{*}$ & $36,14 \pm 1,1^{*}$ \\
\hline Судак & $93,6 \pm 4,4$ & $51,7 \pm 1,8$ & $47,0 \pm 1,6$ & $85,0 \pm 4,5$ & $45,3 \pm 0,5^{*}$ & $34,3 \pm 0,5^{*}$ \\
\hline Лящ & $91,6 \pm 1,5$ & $46,0 \pm 3,9$ & $46,0 \pm 0,8$ & $80,6 \pm 0,9^{*}$ & $41,3 \pm 2,1$ & $33,2 \pm 1,1^{*}$ \\
\hline Плітка & $76,6 \pm 3,1$ & $37,0 \pm 0,4$ & $61,0 \pm 3,3$ & $72,4 \pm 1,3$ & $35,6 \pm 1,3$ & $40,4 \pm 1,2^{*}$ \\
\hline
\end{tabular}

Спираючись на усереднені дані інших авторів (Яржомбек и др., 1986; Hadjinikolova, 2008; Porto et al., 2016), можемо відмітити, що вміст білка у більшості риб із Запорізького водосховища декілька нижчий за рівень, відповідний даному сезону. Це може вказувати на послаблення обмінних процесів у риб, знижені фізіолого-функціональні можливості, що у свою чергу може призводити до зниження імунітету, і як наслідок, до підвищення захворюваності і сприйнятливості до різного роду інфекцій.

У Самарській затоці Запорізького водосховища вміст білка у м'язах досліджуваних видів риб знижувався, але достовірне відхилення на 14 \% було тільки у ляща.

В зябрах достовірне зниження вмісту білка відмічено у хижих риб - на 24 \% у окуня і на 13 \% у судака.

В печінці вміст білка був достовірно знижений у всіх видів риб, у окуня - на 30 \%, у судака - на $27 \%$, у ляща - на $30 \%$, у плітки - на $34 \%$.

М'язова тканина складає основну масу тіла риб і $\epsilon$ найбільш цінною в харчовому відношенні, як для людини, так і для інших ссавців. Зябра риб приймають на себе перший "удар”, викликаний хімічними змінами у водному середовищі, що часто і відбивається на біохімічних показниках в цьому органі. М'язи також можуть слугувати індикаторами забруднень, але у меншій мірі, ніж зябра, нирки і печінка.

Порівнюючи між собою результати, отримані 3 двох ділянок Запорізького водосховища, можемо сказати, що вміст білка в тканинах риб з нижньої ділянки водосховища вищий майже по всіх показниках, ніж у риб з Самарської затоки. Вміст білка в тканинах риб залежить від багатьох факторів, але у першу чергу визначається рівнем розвитку кормової бази. 
Самарська затока $\epsilon$ замуленою ділянкою водосховища 3 великою кількістю мілководь і добре розвинутою природною кормовою базою для риб. Проте оскільки затока відчуває на собі значний антропогенний вплив і стан навколишнього середовища несприятливий через токсичне забруднення, вміст білка в тканинах промислових риб знижений в порівнянні з нижньою ділянкою Запорізького водосховища.

Жир в тілі риб - речовина дуже лабільна не тільки в кількісному, але і в якісному відношенні. Він $\epsilon$ головним енергетичним джерелом, тому кількість його змінюється залежно від віку, сезону року, змін в харчуванні, а також у зв'язку з голодуванням, тривалими міграціями риби тощо. Жир відкладається в певних місцях тіла риби, типових для даного виду.

Жир риб переважно складається з триглицеридів і жирних кислот, як ненасичених (84 \%), так і насичених (близько $16 \%$ ).

Як видно з результатів дослідження, більша кількість загальних ліпідів міститься у м'язовій тканині і печінці мирних промислових риб, таких як лящ, плітка (табл. 2).

Таблиця 2 Вміст ліпідів у тканинах промислових риб Запорізького водосховища (г/100 г сухої маси, $\mathrm{M} \pm \mathrm{m}, n=8$ )

Table 2 The lipid content in tissues of commercial fishes from the Zaporizke Reservoir $(\mathrm{g} / 100 \mathrm{~g}$ of dry weight, $\mathrm{M} \pm \mathrm{m}, n=8$ )

\begin{tabular}{|l|c|c|c|c|c|c|}
\hline \multirow{2}{*}{ Вид риби } & \multicolumn{3}{|c|}{ Нижня ділянка водосховища } & \multicolumn{3}{c|}{ Самарська затока } \\
\cline { 2 - 7 } & м'язи & зябра & печінка & м'язи & зябра & печінка \\
\hline Окунь & $22,3 \pm 0,6$ & $14,1 \pm 1,2$ & $48,3 \pm 1,2$ & $29,3 \pm 0,06^{*}$ & $17,25 \pm 0,5$ & $46,2 \pm 1,1$ \\
\hline Судак & $21,6 \pm 0,02$ & $13,8 \pm 0,9$ & $42,2 \pm 0,3$ & $37,95 \pm 0,03^{*}$ & $16,4 \pm 1,06$ & $44,5 \pm 0,7$ \\
\hline Лящ & $29,9 \pm 0,2$ & $14,2 \pm 0,7$ & $66,1 \pm 2,4$ & $49,9 \pm 0,3^{*}$ & $15,7 \pm 1,8$ & $54,1 \pm 0,99^{*}$ \\
\hline Плітка & $45,85 \pm 0,3$ & $13,7 \pm 1,3$ & $59,1 \pm 1,1$ & $49,1 \pm 0,4^{*}$ & $16,2 \pm 0,8$ & $52,2 \pm 2,1^{*}$ \\
\hline
\end{tabular}

Значна трофічна пластичність та швидке пристосування в кормовому раціоні коропових риб дозволяють їм значною мірою накопичувати ліпіди в печінці, які можуть бути використані як для енергетичних, так і для пластичних потреб. Загальний вміст ліпідів свідчить про активність анаболічних процесів і мобілізацію ліпідів як джерела енергії, або про їх використання в адаптивних перебудовах метаболізму і структурних компонентах клітини. Характер розподілу ліпідів в тканинах і органах різних видів і екологічних груп залежить від умов середовища, рухової активності, віку тощо. У хижаків, які ведуть рухливий спосіб життя, жир витрачається активніше.

Потрібно відмітити, що вилов відбувався в осінній період, після літнього нагулу перед зимівлею, коли у риб накопичується найбільша кількість жиру.

Судячи з отриманих результатів щодо вмісту загальних ліпідів, можемо сказати, що найбільший їх вміст визначався в печінці, меншою мірою ліпіди відкладаються у м'язах. Зябра відзначаються низьким рівнем загального жиру та слабким ліпідним обміном як неспецифічна для їх запасання тканина.

У риб з Самарської затоки відмічено значне збільшення вмісту загальних ліпідів у м'язах: у плітки - на $70 \%$, у ляща - на $67 \%$, у окуня - на $31 \%$ та у судака - на $75 \%$. Підвищений вміст ліпідів у м'язовій тканині риб Самарської затоки може свідчити про порушення обміну речовин через несприятливі умови існування, що виникли в цьому районі. 
В печінці риб виявлено знижений вміст жиру, достовірні відхилення встановлені у мирних риб, у ляща - на $18 \%$, у плітки - на $12 \%$.

Значне зменшення вмісту загальних жирів у печінці досліджуваних риб, відібраних у Самарській затоці, свідчить про загальне порушення ліпідного обміну та процесів накопичення запасних ліпідів.

Необхідною умовою для використання жиру при енергетичному обміні $є$ добре забезпечення організму киснем. В Самарській затоці вода з низьким вмістом кисню, що вірогідно може гальмувати процес накопичення ліпідів. Також негативний вплив численних промислових стоків порушує ліпідний обмін в організмі гідробіонтів, внаслідок чого риба погано переносить зимівлю.

У будь-якому живому організмі, у тому числі у риб, речовинами, що легко мобілізуються в цілях виробництва енергії, $\epsilon$ вуглеводи, і в першу чергу глюкоза і запасний вуглевод глікоген. Глікоген $\epsilon$ резервною формою вуглеводів і зустрічаються фактично у всіх клітинах в різних кількостях.

Результати наших досліджень показали, що вміст глікогену найбільш високий у печінці риб, де відбувається його специфічне запасання (табл. 3). У м'язовій тканині рівень глікогену вищий, чим у зябрах, особливо у хижих риб, які відрізняються високою рухливістю. Це можна пояснити інтенсивним вуглеводним обміном у м'язах, значною потребою глікогену для здійснення швидких рухів, в порівнянні із зябровим епітелієм.

Таблиця 3 Вміст глікогену у тканинах промислових риб Запорізького водосховища (г/100 г сухої маси, $\mathrm{M} \pm \mathrm{m}, n=8$ )

Table 3 The glycogen content in tissues of commercial fishes from the Zaporizke Reservoir $(\mathrm{g} / 100 \mathrm{~g}$ of dry weight, $\mathrm{M} \pm \mathrm{m}, n=8$ )

\begin{tabular}{|l|c|c|c|c|c|c|}
\hline \multirow{2}{*}{ Вид риби } & \multicolumn{3}{|c|}{ Нижня ділянка водосховища } & \multicolumn{3}{c|}{ Самарська затока } \\
\cline { 2 - 7 } & м'язи & зябра & печінка & м'язи & зябра & печінка \\
\hline Окунь & $0,78 \pm 0,03$ & $0,10 \pm 0,01$ & $3,80 \pm 0,05$ & $0,62 \pm 0,01^{*}$ & $0,14 \pm 0,01$ & $2,50 \pm 0,02^{*}$ \\
\hline Судак & $0,93 \pm 0,008$ & $0,17 \pm 0,05$ & $2,80 \pm 0,00$ & $0,66 \pm 0,05^{*}$ & $0,15 \pm 0,02$ & $1,80 \pm 0,06^{*}$ \\
\hline Лящ & $0,74 \pm 0,006$ & $0,15 \pm 0,03$ & $2,20 \pm 0,001$ & $0,81 \pm 0,016$ & $0,20 \pm 0,01$ & $2,10 \pm 0,08$ \\
\hline Плітка & $0,70 \pm 0,03$ & $0,21 \pm 0,016$ & $2,18 \pm 0,001$ & $0,78 \pm 0,03$ & $0,23 \pm 0,04$ & $1,76 \pm 0,06^{*}$ \\
\hline
\end{tabular}

Показники вмісту глікогену в печінці хижих риб виявились вищими у порівнянні з мирними. В печінці плітки та ляща ці показники склали по 2,2 г\%, у хижих риб окуня та судака вони істотно вищі - на 72 та 27 \% відповідно.

У особин промислових видів риб, виловлених у Самарській затоці Запорізького водосховища, спостерігається переважне зниження вмісту глікогену в досліджуваних тканинах та органах. У м'язах окуня показники глікогену знизились на $20 \%$, у м'язах судака - на $29 \%$. У печінці окуня вміст глікогену знизився на 35 \%, у печінці судака - на $36 \%$, плітки - на $20 \%$.

3 отриманих в ході досліджень результатів можна зробити висновок, що антропогенне забруднення Самарської затоки впливає на метаболічні процеси іхтіофауни, і особливо на вуглеводний обмін, оскільки в усіх тканинах та органах досліджуваних нами риб було виявлено зниження показників вмісту глікогену. Отже вуглеводний обмін $\epsilon$ чутливим до змін умов навколишнього середовища. 


\section{Висновки}

У хижих риб у м'язах та печінці спостерігається вищій вміст білка, що пов'язано із особливостями їх харчування. В досліджуваних тканинах хижих риб зафіксовано більший вміст глікогену, оскільки глікоген використовується при необхідності швидкої мобілізації, пов'язаної з кидковими рухами та переслідуванням жертви. Найбільш чутливими до погіршення умов середовища $\epsilon$ вуглеводний та ліпідний обміни, про що свідчить статистично достовірне зниження вмісту глікогену у тканинах риб із "забрудненої" зони водосховища, та порушення обміну ліпідів в тканинах печінки та м'язів. Зниження запасних ліпідів у печінці риб може призводити до порушень в функціонуванні організму. У всіх досліджуваних риб найбільші відхилення біохімічних показників були знайдені у печінці, проте у тканині зябер не виявлено значущих змін у вмісті пластичних і енергетичних речовин. Це свідчить про переважно хронічний характер токсичного впливу на іхтіофауну Запорізького водосховища внаслідок поступового забруднення водного середовища й багаторічної акумуляції токсичних речовин.

Отриманні данні можуть бути використані для оцінки харчової якості досліджуваних промислово-цінних риб водосховища, а також для діагностичних прогнозів екологофізіологічного стану популяцій в умовах антропогенного впливу.

\section{Література}

Fedonenko, E., Ananieva, T. 2016. Biochemical composition of roe and juvenile fish tissues under the various anthropogenic effects upon reservoir. Экологический Вестник Северного Кавказа, т. 12, № 2, c. 35-38.

Fedonenko, O. Sharamok, T. Ananieva, T. 2016. Biochemical parameters of blood in fish from Zaporozhian Reservoir. International Letters of Natural Sciences, vol. 51, pp. 43-50. DOI: 10.18052/www.scipress.com/ ILNS.51.43

Hadjinikolova, L. 2008. Investigations on the chemical composition of carp (Cyprinus carpio L.), bighead carp (Aristichthys nobilis Rich.) and pike (Esox lusius L.) during different stages of individual growth. Bulgarian Journal of Agricultural Science, vol. 14, no 2, p. 121-126.

Porto, H.L.R., de Castro, A.C.L., Filho, V.E.M., Rádis-Baptista, G. 2016. Evaluation of the Chemical Composition of Fish Species Captured in the lower Stretch of Itapecuru River, Maranhão, Brazil. Int'l Journal of Advances in Agricultural \& Environmental Engg. (IJAAEE), vol. 3, no 1, p.181-186. http://dx.doi. org/10.15242/IJAAEE.U0416214

Ананьєва, Т.В., Федоненко, О.В., Півненко Ю.В. 2013. Біохімічний статус тканин як індикатор екологофізіологічного стану промислових риб. Вісник Запорізького начіонального університету, №1, c. 28-34.

Методи гідроекологічних досліджень поверхневих вод. Під ред. В. Д. Романенко. 2006. Київ, 628 с.

Образова, С.Б., Кайрат, Б.К., Шалгимбаева, С.М. и др. 2016. Сравнительный биохимический анализ органов молоди некоторых лососевых рыб при различных условиях выращивания. Вестник АГТУ. Сер.: Рыбное хозяйство, № 4, с. 99-107.

Прохорова, М.И. 1982. Методы биохимического исследования. Ленинград, Изд. ЛГУ, 222 с.

Федоненко, О.В., Єсіпова, Н.Б., Шарамок, Т.С. 2012. Сучасні проблеми гідробіології: Запорізьке водосховище: довідник. Дніпропетровськ: ЛІРА, 280 с.

Яржомбек, А.А., Лиманский, В.В., Щербина, Т.В. 1986. Справочник по физиологии рыб. Москва.: Агропромиздат, 192 с. 